\title{
Effect of spatial and temporal variability of gauged and radar rainfall data on hydrological modelingof urban basins
}

\section{Efeito da variabilidade espaço-temporal de dados observados e de radar de chuva na modelagem hidrológica de bacias urbanas}

\author{
Victor Costa Pontes ${ }^{1}$ (D), Carlos Ruberto Fragoso Jr. ${ }^{1}$ (D), Marllus Gustavo Ferreira Passos das Neves ${ }^{1}$ (D) $\&$ \\ Vladimir Caramori Borges de Souza ${ }^{1}$ (D) \\ ${ }^{1}$ Universidade Federal de Alagoas, Maceió, AL, Brasil \\ E-mails: victorcostapontes@gmail.com (VCP),crubertofj@hotmail.com (CRFJ), marllus.neves@ctec.ufal.br (MGFPN),vcaramori@yahoo.com
} (VCBS)

Received: December 16, 2020 - Revised: May 03, 2021 - Accepted: May 26, 2021

\begin{abstract}
In urban areas, rainfall-runoff modeling provides large uncertainties due to the difficulty in representing the spatial distribution of rainfall events. In this context, the this work aims to evaluate the effect of temporal and spatial of rainfall data (weather radar and distributed rainfall gauges network) on runoff estimation in a urban basin. The Reginaldo basin, inserted in the urban area of the Maceió city, capital of state of Alagoas (Brazil), has a reasonable availability of rainfall datal covered with a high number and spatial distribution of rain gauges and weather radar, which was used as input of a hydrological model The EPA Storm Water Management Model (SWMM) has been used with 3 analysis rainfall scenarios: (i) considering uniform rainfall distribution based on measured average rainfall, (ii) considering distributed rainfall using catchment discretization, and (iii) considering distributed rainfall using radar cell discretization. In order to evaluate the model outcomes, we analyzed four hydrological output variables: (i) the peak flow; (ii) the peak time; (iii) the volume flowed and (iv) the volume losses. Based on this criterion, it was clear that, considering he analyzed scenarios, the effect of spatial distribution of rainfall data on hydrological response in small urban basins, with high impervious coverage, was not divergent for the analyzed scenarios and that the radar data showed significantly higher data resolution than rainfall gauges.
\end{abstract}

Keywords: Hydrologic modelling; SWMM; Remote sensing; Weather radar; Rain gauges stations.

\section{RESUMO}

Nos sistemas de drenagem urbana, as incertezas no cálculo das vazões são grandes, em função da dificuldade na representação da distribuição espacial dos eventos chuvosos. Nesse contexto, o presente trabalho visa avaliar como diferentes informações da espacialização da chuva (radar meteorológico, rede pluviométrica distribuída) e diferentes discretizações espaciais influenciam na estimativa do escoamento superficial. A bacia do Riacho Reginaldo em Maceió/Alagoas é usada como área de estudos, por haver disponibilidade de dados de radar e de uma densa rede de pluviômetros. A área de estudo está totalmente inserida na zona urbana da cidade de Maceió e possui um histórico de alagamentos constantes. O EPA Storm Water Management Model (SWMM) foi utilizado com 3 cenários de análise: (i) com chuva concentrada, considerando a chuva média medida, (ii) chuvas distribuídas por sub-bacias e (iii) distribuído por células do radar. Para avaliar os resultados gerados pelo modelo, foram estipuladas 4 variáveis: (i) a vazão de pico; (ii) o tempo de pico; (iii) o volume escoado e (iv) as perdas. Com base nesse critério, ficou claro que, para os eventos analisados, a distribuição da chuva aplicada a pequenas bacias urbanas com altas taxas de impermeabilização apresenta pouca divergência quanto à discretização da chuva e que o radar apresentou leituras significantemente maiores que as leituras observadas pelos pluviômetros.

Palavras chave: Modelagem hidrológica; SWMM; Sensoriamento remoto; Radar meteorológico; Estações pluviométricas. 


\section{INTRODUCTION}

The uncertainties generated from the rainfall-runoff representation in urban basins are linked to the models and simplifications adopted, the difficulties of estimating the physiographic parameters of the basin, and, mainly, the precipitation estimation. Precipitation is a complex hydrological variable, mainly due to its irregular behaviour in both space and time (Rico-Ramirez et al., 2015).

Rainfall gauge measurements and remote sensing observations show that precipitation fields may largely vary on a spatial scale from a few meters to hundreds of kilometers. Besides, retrieval of spatial distribution of rainfall can lead to large uncertainties considering the methods used for this purpose. In the case of rainfall gauges, retrieval of the average spatial distribution is performed through spatial methods (Adilson Moreira et al., 2007; Cabral et al., 2017). Weather radars, on the other hand, mau improve spatial rainfall resolution, despite the interference of various media and bodies that hinder the use of the product generated as an accurate estimate of rainfall.

The National Center for Monitoring and Natural Disaster Alerts (CEMADEN) has installed a meteorological radar in Maceió and a dense network of rain gauges for monitoring of susceptible regions to natural disasters, improving the performance of civil defense and, consequently, improving representativeness spatial and -temporal monitoring of precipitation. Weather radars are based on microwave emissions and receptions, usually located in high regions, which transmit pulses of electromagnetic waves at regular time intervals, concentrated in a small aperture beam through a rotating antenna, to generate information about rainfall with an average spatial resolution of $1 \mathrm{~km}$ and a few minutes (Hass Miguel, 2018; Calvetti et al., 2003; Adilson Moreira et al., 2007; Barszcz, 2018).

Thus, the search for a better understanding of the spatial and temporal variability of rainfall and its quantification represents an important challenge to better represent the rainfall-runoff relationships (Campos, 2009), especially in urban areas due to the effects of rainfall events on drainage systems. This work explores the relationship between precipitation and runoff events considering concentrated (i.e uniform) and distributed (spatial and temporal variability) rainfall data generated as input to hydrological modelling in a urban basin. This study was applied in the Reginaldo river basin, located in the Maceió city in Alagoas state, since this urban area has a dense rainfall gauge network, the remote rainfall monitoring by a weather radar and previous studies related to the characterization of the basin (Silva Júnior, 2009; Holz, 2010; Pedrosa, 2008, Antonio, 2017).

Most of studies in Brazilian urban basins, which retrieval the runoff events in urban basins using hydrological models considered uniformly distributed precipitation as input data (Leach et al., 2018; Shinma \& Reis, 2014; Pedrosa, 2008; Cabral et al., 2017; Tsuji et al., 2019). This simplification may be explained because low density of rainfall gauges, which are determining factors in the uncertainties of the model results (Tsuji et al., 2019; Rocha Filho, 2010).

At the international scenario, Barszcz (2018) evaluated 18 unique events using data from rain gauges and weather radar and concluded that, in general, the drained volume generated by radar data is significantly lower than that generated by data from rain gauges. Bruni et al. (2015) showed that the effects of spatial and temporal resolution of radar data may affect hydrological models in urban basins. Schuurmans \& Bierkens (2007) evaluated the effect of the distribution of daily rainfall events and confirmed that it is important to assess the effects of the spatial distribution even for daily rainfall monitoring. On the other hand, the effect of the temporal aggregation of rainfall is much more important than the spatial aggregation (Bruni et al., 2015).

Regarding the use of radar data, Cabral et al. (2017) simulated the São Miguel River basin (rural basin) using the HEC-HMS model (Hydrologic Engineering Center - Hydrologic Modelling System) also considering available rainfall gauges. The calibration performed by the author using the Statistical Objective Analysis Scheme - SOAS (Pereira Filho et al., 1998) resulted in a constant parameter for all radar readings.

\section{METHODOLOGY}

In order to assess the potential impacts of the uncertainties of the spatial distribution of rainfall on runoff events in urban areas, we consider three different scenarios for rainfall-runoff simulation: 1) uniform spatial distribution of rainfall in the basin; 2) Spatial variability of precipitation at catchment scale; 3) Spatial distribution of precipitation considering rainfall cells from weather radar.

For these scenarios, we evaluated the sensitive parameters of the models, including the transformation of the radar measurements into precipitation. We adopted the initial values of hydrological model parameters based on previous studies (Pedrosa, 2008). As input of hydrological model, we used the available radar data and the rain gauge network installed from 2012 by CEMADEN.

For a better understanding of the methodology, the Figure 1 shows a flowchart of the used data and how the data were processed to obtain the model results of this work.

\section{Hydrological and Hydrodynamic Model}

The choice of the hydrological model was based on several studies around the world such as the work developed by Shinma (2015), who conducted an analysis on hydrological models and highlighted that SWMM model (United States Environmental Protection Agency, 2017) has greater flexibility to simulate a hydrological event in urban environments compared to other models, such as IPHS1, HEC, and MOUSE.

SWMM is a dynamic rainfall-runoff model, designed to simulate water runoff and contaminants in response to single or continuous rainfall, especially in urban watersheds (Rossman, 2015).

The hydrological model is based on a set of catchments with their respective parameters (usually homogeneous areas of land use and land cover are used to avoid errors related to the determination of parameters), where the precipitation will be transformed into flow discharge. The hydrological model allows the use in different configurations for spatial discretization of the basin and/or for the spatial and temporal discretization of precipitation, including the simulation for events or continuous series. 


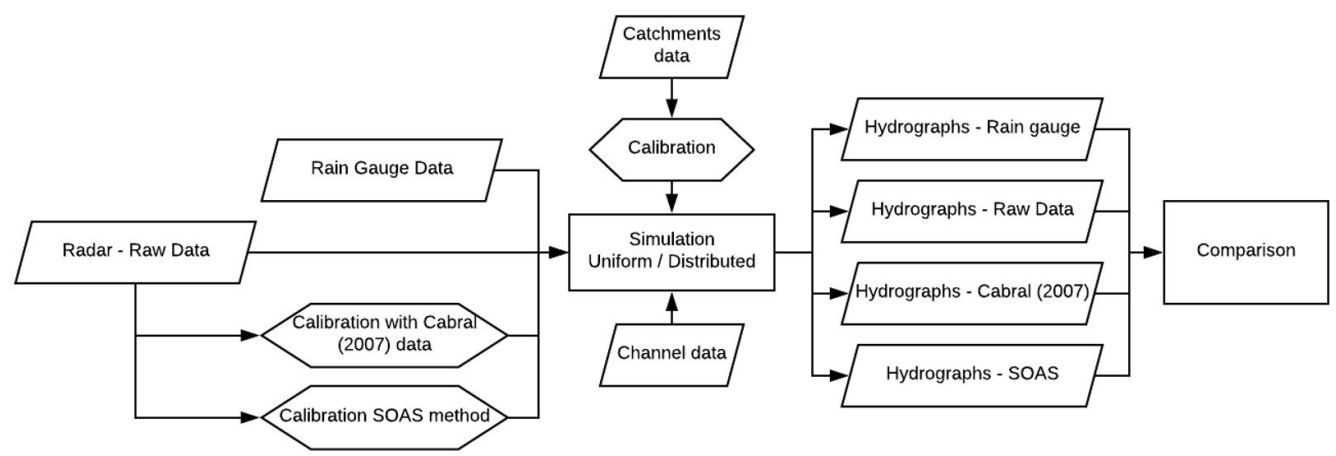

Figure 1. Flowchart of data collection and processing methodology.
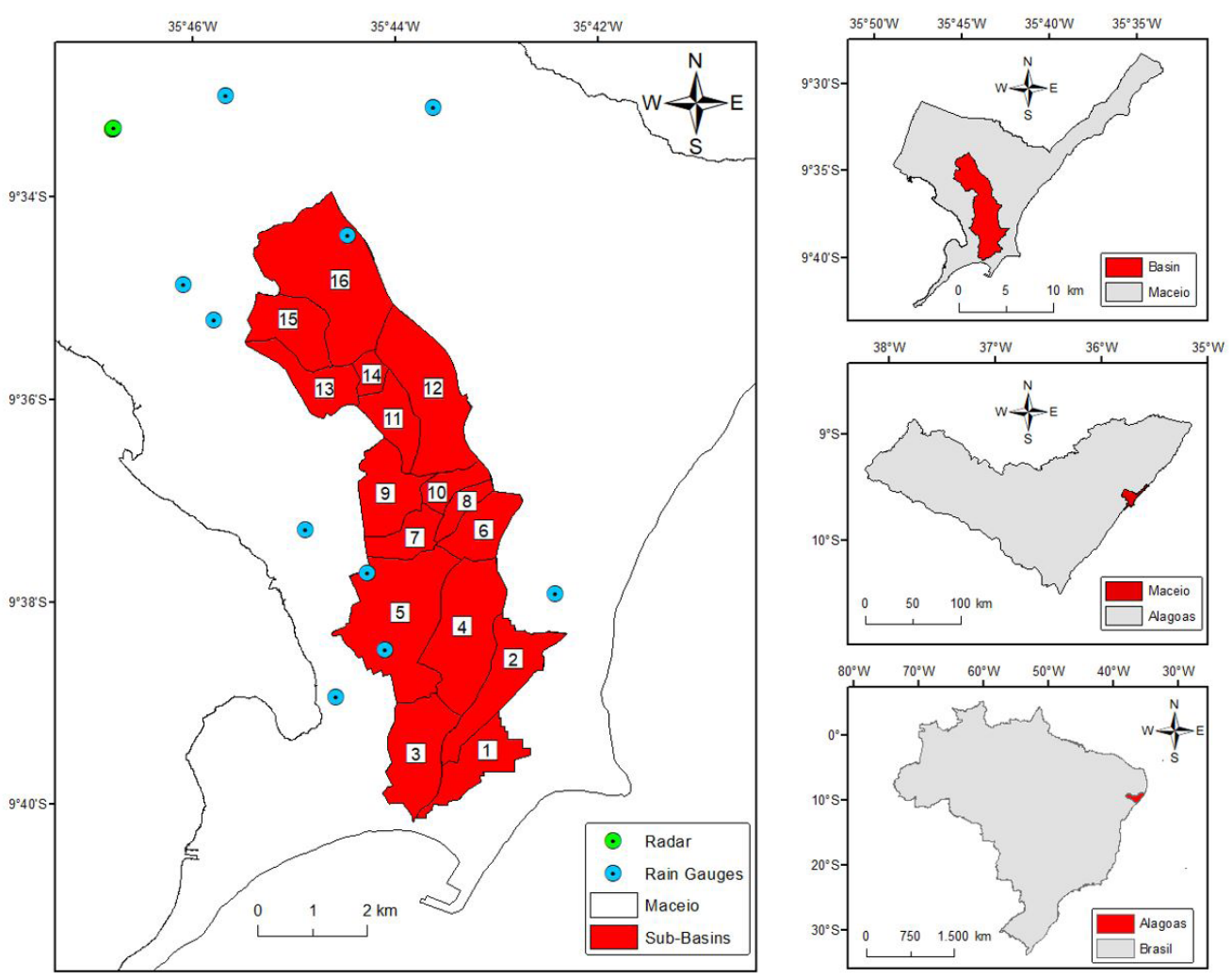

Figure 2. Location of the study area. The division of the basin was carried out by Pedrosa (2008) according to the zones of interest, topography and land use and occupation.

Rainfall-runoff transformation considers that the sub-basins work as non-linear reservoirs. Flow discharge occurs through the balance between precipitated (concentrated and distributed model), infiltrated, evaporated, stored (initial losses), and drained water. The flow (parameter of interest of this work) is based on the combination of the Manning equations and continuity.

The discharged volume in each catchment is moved to its respective outlet, in which all the catchment outlets are interconnected, leading the total discharged volume to basin exit. Between two outlets, there is a river channel, in which the flow is propagated according to the kinematic wave model that uses the equation of continuity in the sub-basin outlets, and for the river junctions are adopted the equation of continuity together with a simplified form of the equation of the moment.

\section{Study Area}

The Reginaldo stream Basin (Figure 2) is in Maceió urban area (Pedrosa, 2008; Holz, 2010; Antonio, 2017), covering an area of $26.5 \mathrm{~km}^{2}$, with a concentration-time of $155 \mathrm{~min}$. The basin perimeter equal to $34.78 \mathrm{~km}$ and the length of the main river is equal to $14.8 \mathrm{~km}$. The average slope of the main river equal to $0.007 \mathrm{~m} / \mathrm{m}$, maximum elevation equal to $98 \mathrm{~m}$, minimum elevation at sea level. The basin has an elongated shape, flat areas in the lower part of the basin, and steep areas in the higher part of the basin (Pedrosa, 2008).

The basin was divided into 16 catchments (Pedrosa, 2008) considering topography, cover and land use, and urban occupation. The characteristics of the catchments required for the SWMM hydrological model simulation are: area, width, average slope, impervious area, Manning coefficients for urban and 
non-urban areas, volume stored in the catchment, which there is flow discharge between urban and non-urban areas, evaporated volume, infiltrated volume and underground flow. The infiltrated volume was determined using the SCS-CN (Soil Conservation Service - Curve Number) method and the kinematic wave model for channel flow propagation. Surface propagation occurs with a non-linear model. The volume stored in the basin and the flow between sub-areas were considered zero. The evaporated volume was considered zero because during a rainy event the evaporation is practically null. Table 1 presents the parameters used in the transformation rain-zone determined by Pedrosa (2008) and the remaining parameters will be addressed later.

The characteristic width and coefficients of Manning were determined through the automatic calibration in PCSWMM (Smith et al., 2005) using RMSE (root mean squared error), which requires a starting point. In this way, a value for the Manning coefficient has been adopted, which is consistent with the land cover $(0.014$ for the impervious area and 0.15 for the permeable area - Rossman, 2015). For the basin characteristic width was adopted the value calculated from Equation 1.

$$
W=A / L
$$

where $\mathrm{W}$ is the characteristic basin width, $\mathrm{A}$ is the catchment area and $\mathrm{L}$ is the length of the main river.

The calibration is performed by simulating the previously determined data and the observed data. In this work, the results obtained by Pedrosa (2008) will be used as the reference data. Pedrosa (2008) in his work performed simulations for different design rainfalls with return periods equal to 2, 10 and 50 years.

For hydrodynamic modelling (flow propagation in channels) were necessary parameters, such as channel cross-section, length of sections, roughness, maximum channel depth, upstream and downstream elevations. The channel cross-section and roughness were considered constant throughout the entire basin due to lack of data and difficulty in characterization. The roughness was determined as the lowest value of a concrete channel (determined through the SWMM manual), i.e., equal to 0.011 so that the channel has the lowest flow resistance. The cross-section was chosen as a rectangular channel with a base width equal to $5 \mathrm{~m}$ and a height large enough to allow flow discharge. Table 2 shows the parameters used for flow propagation.

\section{Simulated event}

For the simulations, events that promote flooding in the basin were selected (as shown in Table 3), considering the data available from local institutions, or that presented availability of radar data. The beginning of the events occurred from the first measurement with at least one rain gauge with a value higher than zero and accumulated precipitation in $1 \mathrm{~h}$ greater than $1 \mathrm{~mm}$. Moreover, we established that the end of events would occur when all rain gauges had accumulated measurement of $1 \mathrm{~h}$ below $1 \mathrm{~mm}$.

The events were also evaluated according to the IntensityDuration-Frequency (IDF) curve used for drainage projects in Maceió. Two curves are available: Pfafstetter (1957) and Denardin \& Freitas (1982). The curve determined by Pfafstetter (Equations 2 and 3),
Table 1. Parameters defined by Pedrosa (2008).

\begin{tabular}{ccccc}
\hline $\begin{array}{c}\text { Sub- } \\
\text { catchment }\end{array}$ & Area (ha) & Slope (\%) & $\begin{array}{c}\text { Waterproof } \\
\text { area (\%) }\end{array}$ & CN \\
\hline S1 & 126.7 & 0.18 & 89.5 & 90 \\
S2 & 172.0 & 2.41 & 76.5 & 92 \\
S3 & 193.2 & 1.07 & 76.9 & 92 \\
S4 & 273.4 & 1.51 & 79.3 & 94 \\
S5 & 363.8 & 2.13 & 65.8 & 95 \\
S6 & 107.6 & 5.49 & 40.9 & 94 \\
S7 & 78.7 & 2.44 & 66.2 & 94 \\
S8 & 43.1 & 5.40 & 58.2 & 94 \\
S9 & 145.3 & 2.13 & 75.1 & 91 \\
S10 & 56.4 & 1.79 & 50.8 & 92 \\
S11 & 100.0 & 1.03 & 50.1 & 90 \\
S12 & 284.3 & 1.14 & 39.3 & 93 \\
S13 & 114.3 & 1.14 & 43.6 & 88 \\
S14 & 36.1 & 4.03 & 61.2 & 87 \\
S15 & 139.4 & 1.01 & 20.6 & 91 \\
S16 & 411.3 & 0.51 & 30.9 & 93 \\
\hline
\end{tabular}

Table 2. Channel data.

\begin{tabular}{cccc}
\hline Channel & $\begin{array}{c}\text { Upstream } \\
\text { quota }(\mathbf{m})\end{array}$ & $\begin{array}{c}\text { Downstream } \\
\text { quota }(\mathbf{m})\end{array}$ & Length (m) \\
\hline C1 & 84 & 54 & 858 \\
C2 & 54 & 46 & 2060 \\
C3 & 46 & 45 & 822 \\
C4 & 45 & 39 & 866 \\
C5 & 39 & 28 & 3829 \\
C6 & 28 & 10 & 830 \\
C7 & 10 & 1 & 890 \\
C8 & 1 & 0 & 901 \\
\hline
\end{tabular}

which according to Pedrosa (2008) and Santos (2018) is the most used in the city, was chosen.

$$
\begin{aligned}
& P=R *\left[a * t+b * \log \left(1+c^{*} t\right)\right] \\
& R=\operatorname{Tr}\left(\alpha+\frac{\beta}{T r^{\gamma}}\right)
\end{aligned}
$$

where $\mathrm{P}$ is the maximum precipitation in $\mathrm{mm}, \mathrm{t}$ is the duration in hours, a, b and c are constants for each station equal to $0.5,29$ and 10 respectively, $\mathrm{R}$ is the probability factor, $\operatorname{Tr}$ is the return period, $\alpha$ and $\beta$ are parameters that depend on the duration of the event and $\gamma$ is a constant equal to 0.25 .

The characterization of the events concerning the return period for each duration is presented in Figure 3, where it is observed, for example, that the event that occurred on $01 / 28 / 2019$ presented high intensity during a continuous interval of 30 minutes (more than 10 years of return period) but decreased the intensity for the total duration of the event. Table 3 presents the selected events.

Lee et al. (2018) and Barco et al. (2008) evaluated results of the methods for determining average rainfall, concluding that the method that best approximates reality is Thiessen's, but that the inverse of the square of distance and kriging also showed good results. Thus, the Thiessen Polygon method was chosen for rain spatialization, as shown in Figure 2, where the location of the available rain gauge stations is observed, this method will be applied for all scenarios. 


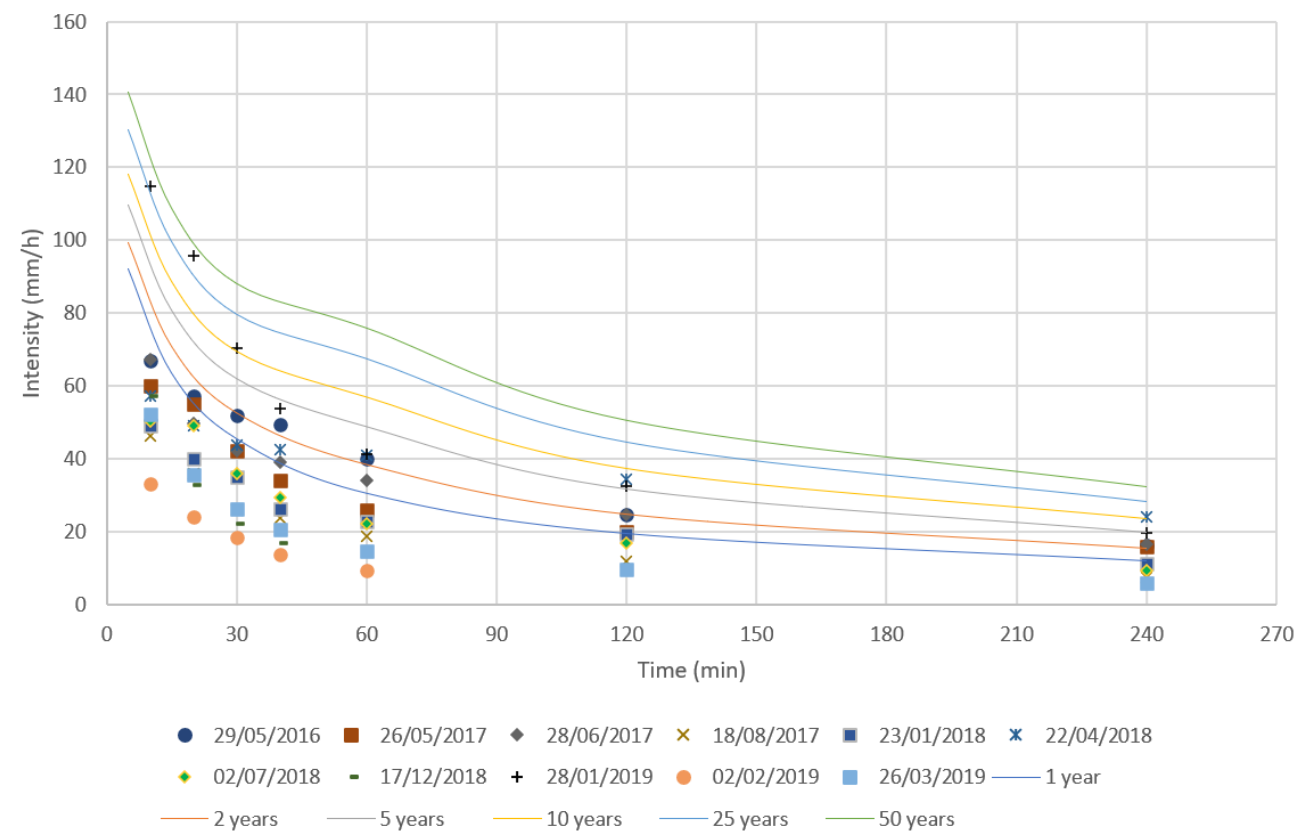

Figure 3. Estimation of the return periods of the selected events, for each duration, considering the IDF curve of Pfafstetter (1957) for Maceió.

Table 3. Summary of selected events.

\begin{tabular}{|c|c|c|c|c|c|c|}
\hline Event & Duration & Total Rainfall & $\begin{array}{l}\text { Average } \\
\text { intensity }\end{array}$ & Return period & $\begin{array}{l}\text { Occurrence of } \\
\text { flooding }\end{array}$ & $\begin{array}{c}\text { Available radar } \\
\text { data }\end{array}$ \\
\hline$\overline{(d d / m m / y y y y)}$ & (min) & $(\mathrm{mm})$ & $(\mathrm{mm} / \mathrm{h})$ & (years) $^{*}$ & & \\
\hline $05 / 29 / 2016$ & 920 & 53.92 & 3.52 & 2.4 & Yes & No \\
\hline $05 / 26 / 2017$ & 1200 & 169.17 & 8.46 & 2.2 & Yes & No \\
\hline $06 / 28 / 2017$ & 590 & 66.55 & 6.77 & 2.5 & Yes & No \\
\hline $08 / 18 / 2017$ & 440 & 31.41 & 4.28 & $<1$ & Yes & No \\
\hline $01 / 23 / 2018$ & 270 & 16.72 & 3.72 & $<1$ & Yes & No \\
\hline $04 / 22 / 2018$ & 690 & 129.53 & 11.26 & 11 & Yes & No \\
\hline $07 / 02 / 2018$ & 190 & 25.29 & 7.99 & $<1$ & Yes & No \\
\hline $12 / 17 / 2018$ & 50 & 6.18 & 7.42 & $<1$ & No & Yes \\
\hline $01 / 28 / 2019$ & 500 & 84.07 & 10.09 & 5 & Yes & No \\
\hline $02 / 02 / 2019$ & 80 & 5.56 & 4.17 & $<1$ & No & Yes \\
\hline $03 / 26 / 2019$ & 230 & 18.77 & 4.90 & $<1$ & No & Yes \\
\hline
\end{tabular}

* Return period considered for the basin concentration-time, equal to 155 minutes (calculated by the Kirpich method), according to Pedrosa (2008) and using the IDF curve of Pfafstetter (1957), used as a reference for hydraulic projects in Maceió.

The use of the Thiessen Polygon method first determined which stations contribute to the basin and only 8 stations present readings with 10-minute time resolution, which have available data and influence on the basin. It should be noted that the radar readings from the event that occurred on $12 / 17 / 2018$ presented many interferences, which made it impossible to use them in modelling.

\section{Radar data}

The CEMADEN weather radar in Maceió/AL is located at the coordinates $9.55129^{\circ} \mathrm{S}$ and $35.77068^{\circ} \mathrm{O}$. The radar is operated in the S-band, doppler and double polarization, which allows the measurement of the amount, diameter and distance that drops of rainfall through the reflectivity of electromagnetic waves. The transformation of reflectivity into rain is given by Equation 4, also known as Z-R ratio (Rico-Ramirez et al., 2015).

$$
Z=a R^{b}
$$

where $\mathrm{Z}$ is the reflectivity $\left(\mathrm{mm}^{6} / \mathrm{m}\right), \mathrm{R}$ is the precipitation rate $(\mathrm{mm} / \mathrm{h})$, a and $\mathrm{b}$ are constant.

The parameters "a" and "b" can be determined by the meteorological or statistical method. In the meteorological method, both the reflectivity and the precipitation rate are obtained directly by the radar, which detects the size of the water drops, and subsequently adjusted the values of "a" and " $b$ ". On the other hand, the statistical method is based on a time series of drop spectra. A notable issue with both methods is that different droplet spectra can generate the same reflectivity, but this error is reduced when the integration time interval is long (Barszcz, 2018).

Tayob (2014) and Tenório et al. (2012) through statistical analysis determined the values of "a" and "b" for the city of Maceió and Marshall \& Palmer (1948) determined standard values for regions without data, as shown in Table 4. 
It is worth mentioning that the coefficients "a" and "b" depend on the type of rain, the location, the volume of the drops, the period in which the rain occurs, among others. Thus, the larger the studied series, for the validation of the coefficients, the better the results will be.

The information from the radar is available in extensions *.h5 and *.tiff. The files in extension *.h5 are information read by the radar as reflectivity, radial velocity, spectral width, differential reflectivity, among others. On the other hand, retrieval precipitation data as *.tiff images were calculated by Equation 4 using the coefficients determined by Marshall \& Palmer (1948). CEMADEN uses the Py-ART library (Python ARM Radar Toolkit) to perform the treatment of radar data.

The pixels that make up the basin were then determined using the ArcGIS tool (Environmental Systems Research Institute, 2018) by combining the radar images (and their spatial resolution) with the basin delimitation (according to Pedrosa, 2008), shown in Figure 4.

After getting all precipitation values in the image pixels and observed data from the rainfall gauge stations, it was possible to perform the calibration to obtain a better result. In this work, the parameter determined by Cabral et al. (2017) and the SOAS (Statistical Objective Analysis Scheme) were considered. Cabral et al.

Table 4. Values of "a" and "b".

\begin{tabular}{ccc}
\hline Z-R relation & a & b \\
\hline Tayob (2014) & 123 & 1.27 \\
Tenório, Moraes e Sauvageot (2012) & 146 & 1.28 \\
Marshall e Palmer (1948) & 200 & 1.60 \\
\hline
\end{tabular}

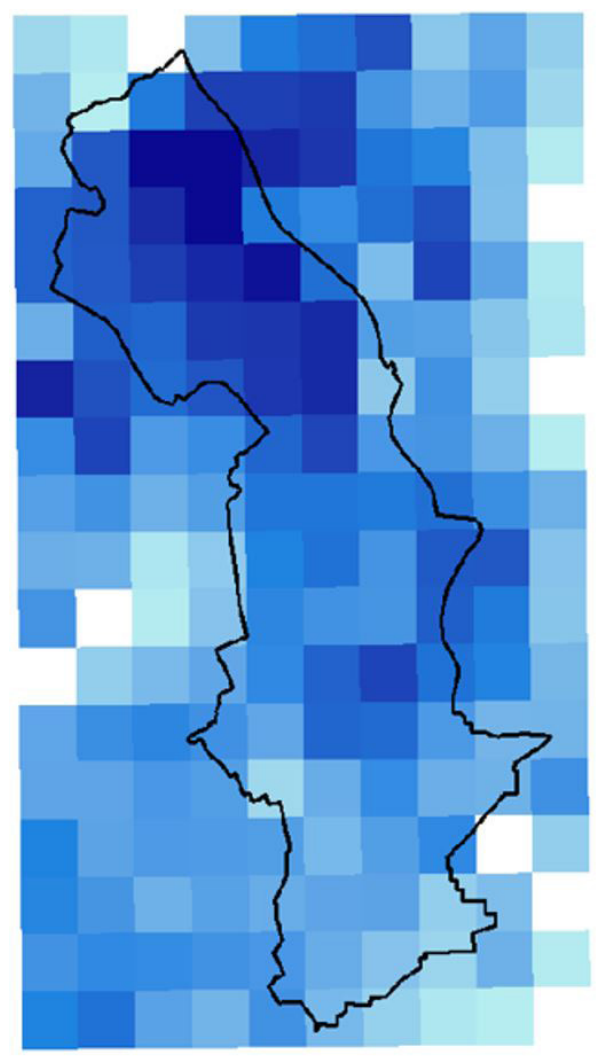

(a)
(2017), in their work, determined that the radar readings could be calibrated by a constant parameter for all radar pixels used in this work. On the other hand, the SOAS is an efficient interpolation technique that reduces the analysis variance using rain gauge data. This method aims to maximize the precipitation signal and minimize the observational errors to generate an analysis with minor errors when comparing it to an analysis using only radar or rain station data. The SOAS equation is given by:

$P_{a}\left(x_{r}\right)=P_{b}\left(x_{r}\right)+\sum_{1}^{n} W_{n}\left[P_{0}\left(x_{n}\right)-P_{c}\left(x_{n}\right)\right]$

where $\mathrm{P}_{\mathrm{a}}$ is the corrected precipitation, $\mathrm{P}_{\mathrm{b}}$ is the estimated precipitation by the radar ("background"), $\mathrm{P}_{\mathrm{o}}$ is the precipitation measured by the rain gauge ("observation"), $\mathrm{P}_{\mathrm{c}}$ is the precipitation estimated by the radar in the rain gauge, $\mathrm{W}_{\mathrm{n}}$ is the a posteriori weight to be determined by the network data setup, $\mathrm{N}$ is the total number of rainfall gauge, $\mathrm{xr}$ and $x n$ are the respective grid positions of the radar and rain gauge.

To derive the weights, it must be assumed that the observation errors and the rainfall estimated by the radar are unrelated and bias-free. The expected variance of the analysis error is minimized concerning the "W" weights (derived from Equation 5). The normalized expression for the weights is given by Equation 6 .

$$
\sum_{1}^{n}\left[W_{n}\left(\rho_{k i}+\varepsilon_{k i}{ }^{2}\right)\right]=\rho_{j i} ; p / 1 \leq k \leq N
$$

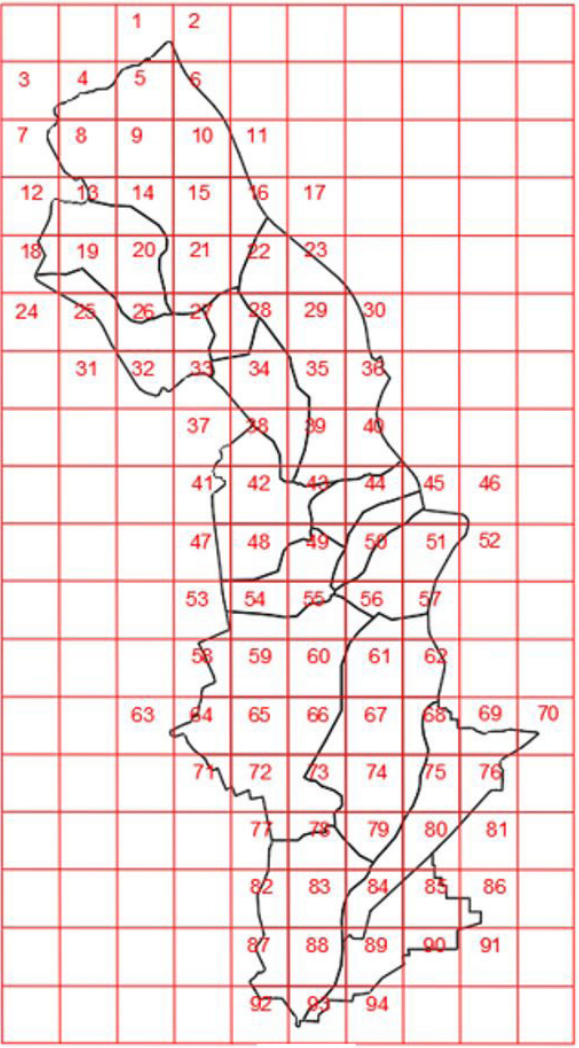

(b)

Figure 4. a) Discrete radar reading and b) Pixels influencing the basin (673.6x673.6 m). 
where $Q_{k i}$ is the correlation between the background error in rain gauges " $\mathrm{k}$ " and " $\mathrm{i}$ ", $\varepsilon_{\mathrm{ki}}{ }^{2}$ is the standardized observational error, $\varrho_{\mathrm{ij}}$ is the correlation between the background error in rain gauges "i" and grid point " $j$ ".

Equation 6 can be normalized as:

$\varepsilon_{a}^{2}=1-\sum_{1}^{N} \rho_{k i} * W_{i}$

Equations 6 and 7 are normalized through the radar error covariance matrix (background). This matrix is the most important component of the SOAS, directly influencing the accuracy of the analysis. Not considering the impact of background error negatively affects the interpolation errors.

The SOAS combines simplicity and robustness to maximize the accuracy of the rain estimate at grid points and, at the same time, minimize the error of the analysis such that it is smaller than the smallest observational error (Pereira Filho et al., 1998). The main advantages of this method are: the expected variance of the analysis error is minimized, the method uses statistical properties of precipitating systems, only points close to the point of analysis are used in interpolation and the method is simple and relates to the physical properties of interest.

The complete development of the equations can be found in the work developed by Pereira Filho et al. (1998).

Tests using this technique were done by Calvetti et al. (2003), showing that the integration of information becomes important not only for the analysis of isolated precipitation systems but also for frontal systems providing more appropriate estimates for hydrological studies in river basins.

Finally, after calibration, the determination of rainfall is performed through the Thiessen Polygon method where the area of each pixel replaces the area of influence of the posts.

\section{RESULTS AND DISCUSSION}

\section{Determination of the Remaining Parameters}

First, a parameterization was performed to adjust the model adopted to the results obtained by Pedrosa (2008). This result tries to establish a higher level of confidence in the results to reduce the occurrence of failures in the simulations due to the parameters adopted in the models. The hydrographs resulting from the parameterization and the hydrographs generated by Pedrosa (2008) are present in Figure 5.

The calibration results try to reduce the differences between the reference hydrographs and those modelled so that the sum of the difference between the curves is the closest to zero. Even presenting relatively high differences, it can be justified by the difference between the models used, which according to Souza (2017) the representation of the same event in different hydrological models can present variations of up to $100 \%$.

The values of the Manning coefficients and the parameterized characteristic widths are in Table 5 and through the physiographic characteristics of the basin the coherence of the results was evaluated through parameters and reference equations present in the SWMM manual.

\section{Discharge simulation with Rainfall gauge stations}

With the parameterized hydrological model, runoff simulations were carried out using rain gauge data for all scenarios and outcome variables were calculated for each event. To examine

Table 5. Parameterized values of width and Manning coefficient

\begin{tabular}{cccc}
\hline $\begin{array}{c}\text { Sub- } \\
\text { catchment }\end{array}$ & Width (m) & N-imp & N-perm \\
\hline 1 & 607.1 & 0.019 & 0.132 \\
2 & 884.3 & 0.019 & 0.124 \\
3 & 623.5 & 0.019 & 0.139 \\
4 & 923.8 & 0.019 & 0.117 \\
5 & 2057.9 & 0.018 & 0.072 \\
6 & 1569.3 & 0.017 & 0.009 \\
7 & 694.0 & 0.018 & 0.128 \\
8 & 644.8 & 0.017 & 0.158 \\
9 & 1390.7 & 0.018 & 0.094 \\
10 & 292.2 & 0.017 & 0.181 \\
11 & 319.7 & 0.018 & 0.164 \\
12 & 754.7 & 0.017 & 0.009 \\
13 & 296.6 & 0.017 & 0.155 \\
14 & 431.3 & 0.017 & 0.161 \\
15 & 351.5 & 0.018 & 0.156 \\
16 & 568.9 & 0.017 & 0.134 \\
\hline
\end{tabular}

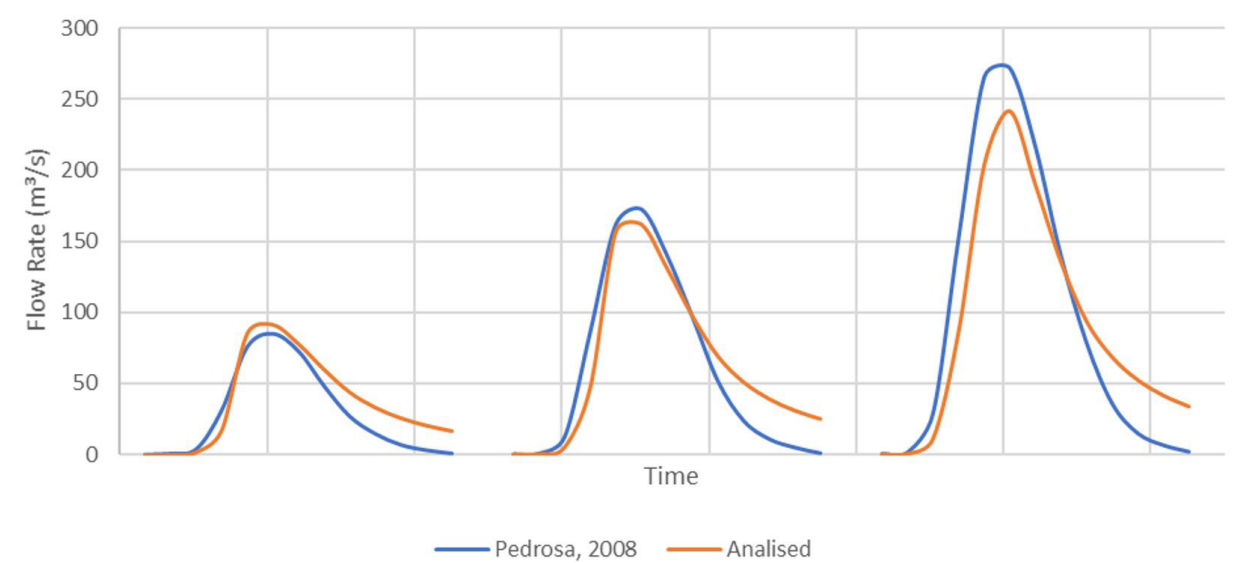

Figure 5. Result of parameterization for three different events. 
the correspondence between the scenarios, events that caused flooding were selected, which had large volumes of precipitation. The results of the comparison are present in Figure 6 that shows the good correspondence among them, the event that occurred on $05 / 29 / 2016$ (highlighted) was used to analyse the behaviour between the scenarios.

For a deeper analysis, the hydrographs and isohyet corresponding to the event of $05 / 29 / 2016$ (diamond point in Figure 6) were plotted (Figure 7). Observing the precipitation isohyets, it is notable a greater precipitated volume far from the basin outlet (most permeable region) which causes the increase of the infiltrated volume in the distributed model, reducing the flow volume and the peak flow.

Analysing the precipitated volume through the results of each sub-catchment, the divergence between the analysed scenarios can be observed. In the distributed model, the precipitated volume in 6 sub-catchments $(11,12,13,14,15$ and 16 represents $41 \%$ of the total area) presented $66 \%$ of all the precipitated volume and only catchment 16 presented $28 \%$ of the total (Figure $8 \mathrm{~B}$ ). This is repeated for the other parameters (Figure 8).

This large variation in results is justified by the development of the rainy event having occurred in a concentrated way in the upper part of the basin that has lower waterproofing rates,

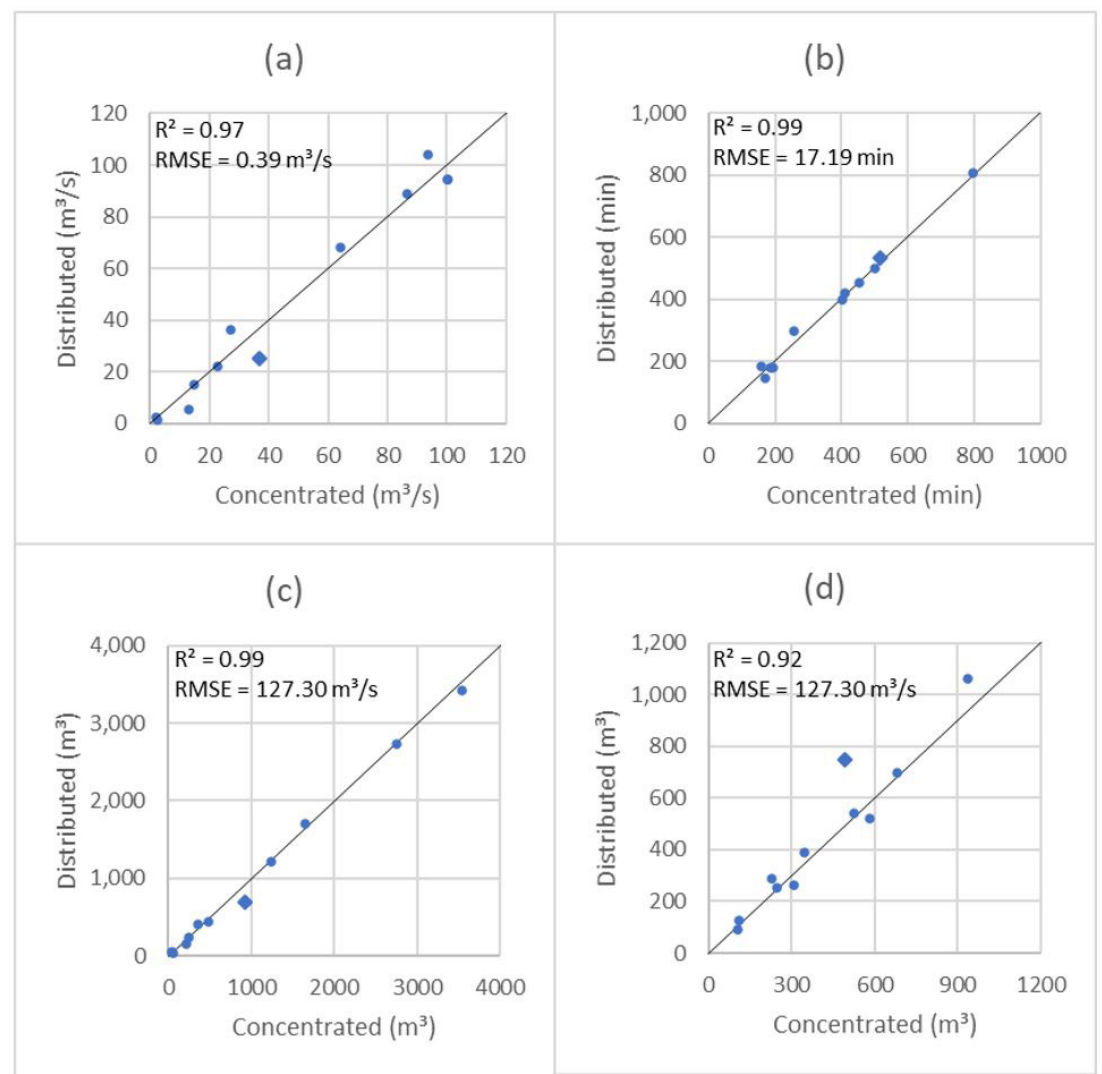

Figure 6. Comparison between the parameters of the evaluated scenarios: a) Peak flow, b) Peak time, c) Flowed volume and d) Inlet volume.
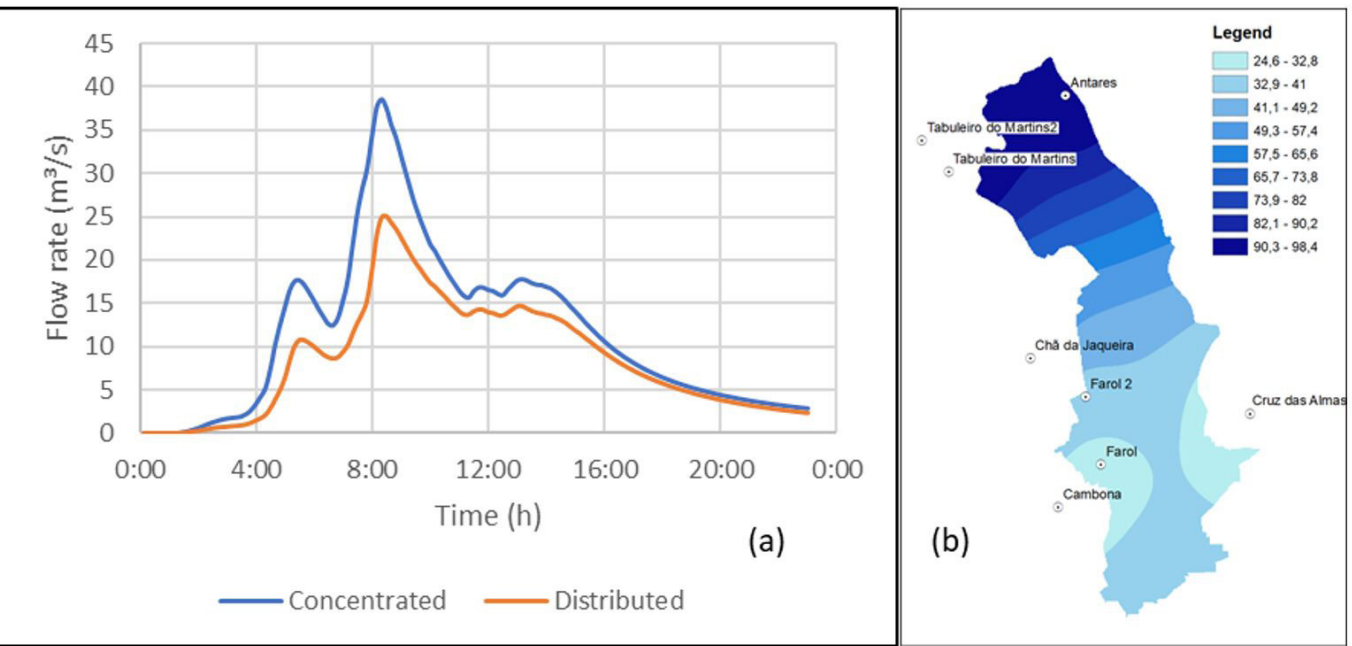

Figure 7. a) Hydrographs day 05/29/2016 and b) isohyet - legend in mm. 


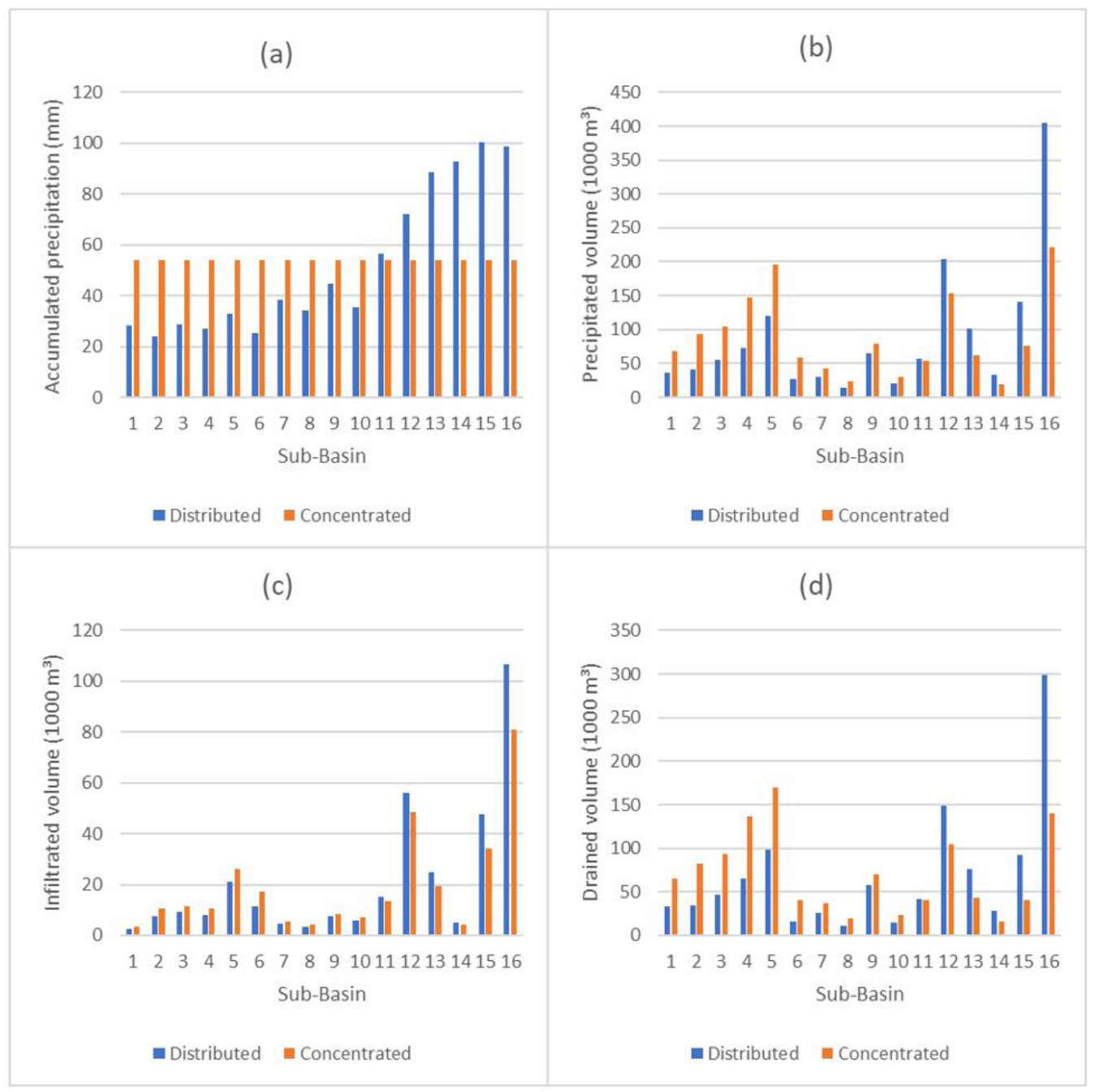

Figure 8. Results per sub-catchment. a) accumulated precipitation, b) precipitated volume, c) infiltrated volume and d) drained volume.

which led to variations in hydrographs. Another important fact is how the characteristics of the sub-catchments influence the runoff, in the concentrated model, the precipitation is homogeneous throughout the basin (Figure 8A), sub-catchments $6,7,8,10,11,14$ and 15 are responsible for only $15 \%$ of all the volume drained.

Another important event for the study of the space-time variability of rainfall is that which occurred on $04 / 22 / 2018$, which presented two behaviours, as shown in Figure 9.

The first behaviour occurred in the first 6 hours when the highest precipitated volume fell over the upper region of the basin (Figure 9(2)). The second one occurred after 6 hours and presented the opposite behaviour to the first one, where the greater precipitated volume fell on the lower region of the basin (Figure 9(4), more impermeable region), causing the inversion of hydrographs.

\section{Discharge simulation with Radar Data}

For the radar data, both scenarios were simulated using the raw radar data, the radar data calibrated by the coefficient determined by Cabral et al.(2017) and the SOAS. figure 10 shows the flow rate at the time of the rainy event that occurred on $02 / 02 / 2019$.
For the event that occurred on $02 / 02 / 2019$, the hydrographs (Figure 10) show large variations when compared to the hydrograph resulting from the simulation with the data from the rain gauge stations, and the results calibrated by the SOAS are similar to the hydrographs.

Another event with available radar data was the event that occurred on March 26, 2009. This event was treated analogously to the previous one and its hydrographs are present in figure 11.

We verified that the raw radar data required correction and that after the applied correction coefficient the estimated hydrographs were closer to the observed hydrographs obtained by the rain gauge data (figure 11). But unlike what happened on $02 / 02 / 2019$, the event of $03 / 26 / 2019$, besides presenting great variations, generated a localized peak. To understand this localized peak, we compared the hyetographs of the concentrated model using radar data and rain gauge stations.

Figure 12 shows the hyetographs of the event 03/26/2019 that have the same trends and the divergence between the hydrographs is justified by the magnitude of the radar data, that when applying the correction methods, the intensity of the rain is reduced and the estimated hydrographs tend to approach the hydrographs generated by the data of the rain gauge stations.

Finally, by analysing the accumulated rainfall in any time interval, the spatial difference generated by the measurement 

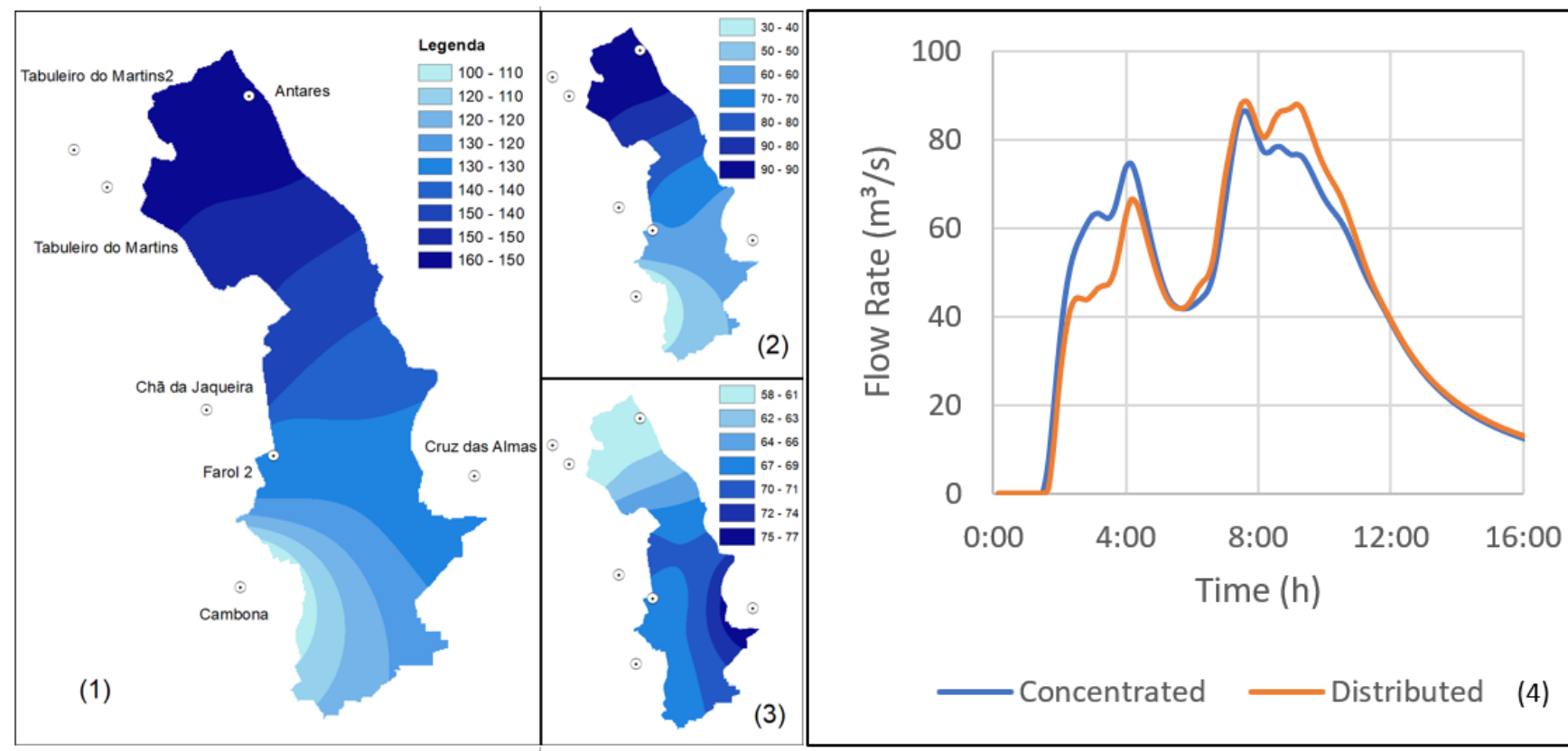

Concentrated $\quad$ Distributed

Figure 9. isohyet: 1) Complete event, 2) First 6h and 3) Last 6 hours - subtitles in mm; 4) Hydrographs day 04/22/2018.

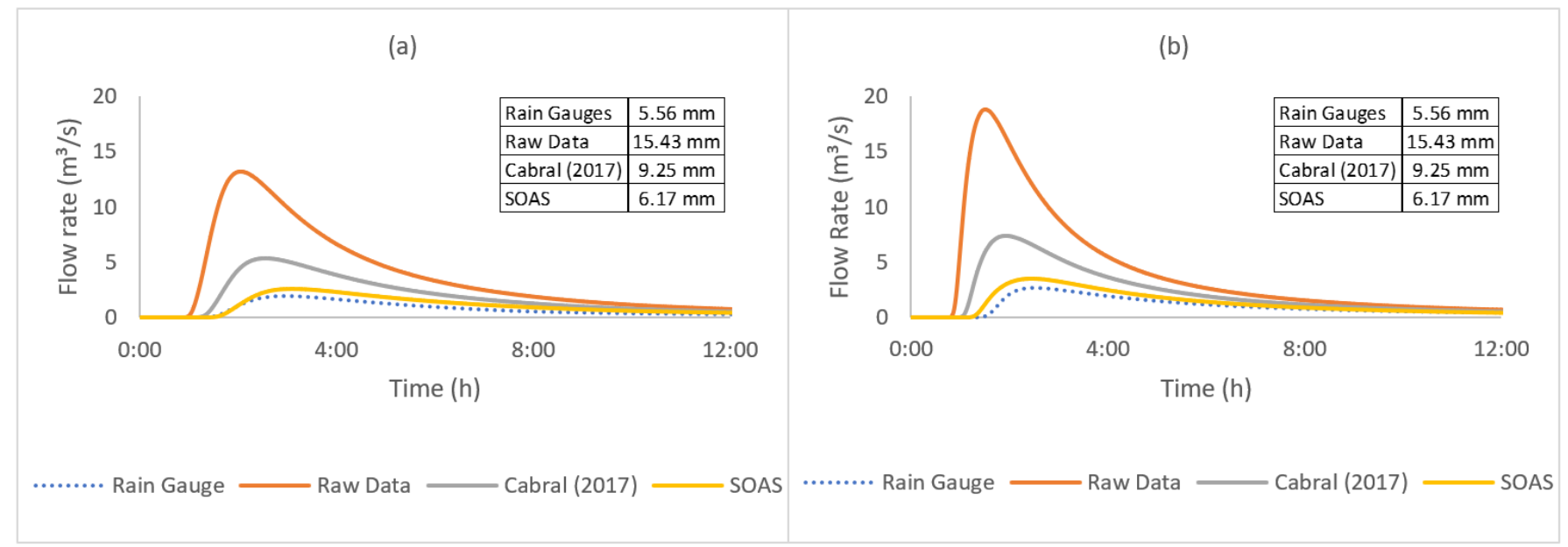

Figure 10. Hydrographs day 02/02/2019: a) Concentrated and b) Distributed.

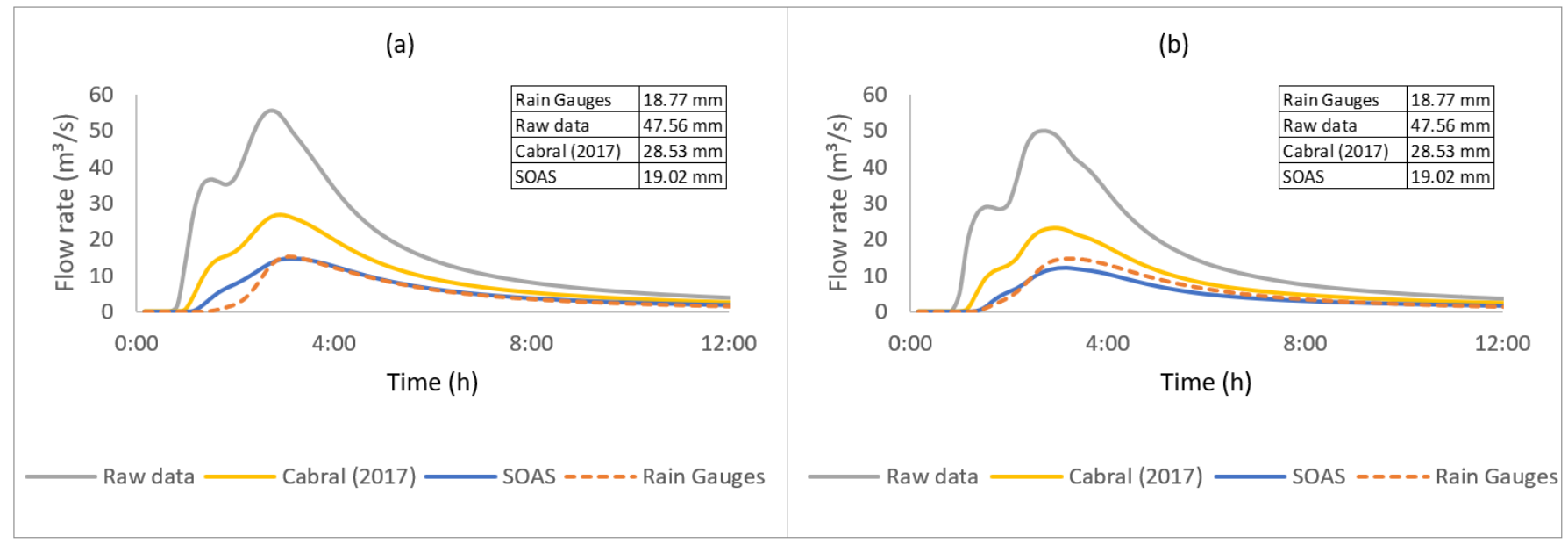

Figure 11. Hydrographs from 03/26/2019: Models a) Concentrated and b) Distributed. 


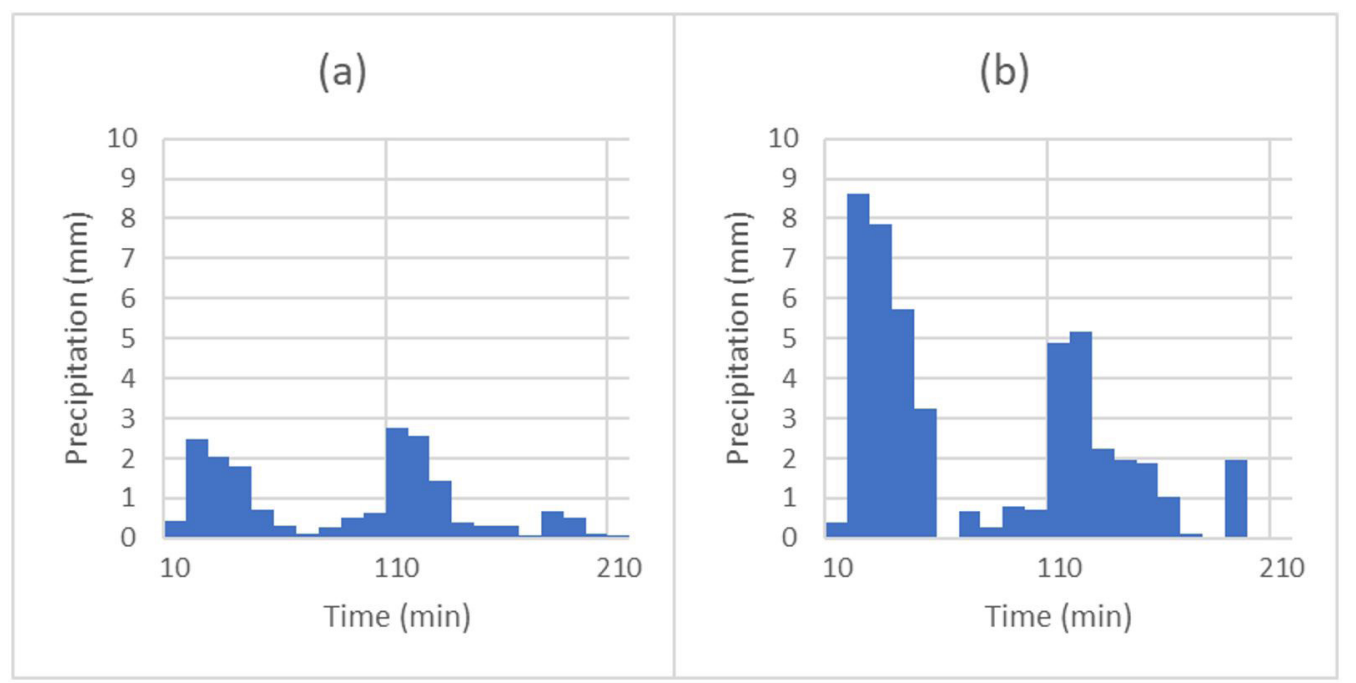

Figure 12. Hyetographs generated by: a) Rain gauges and b) Raw radar data.

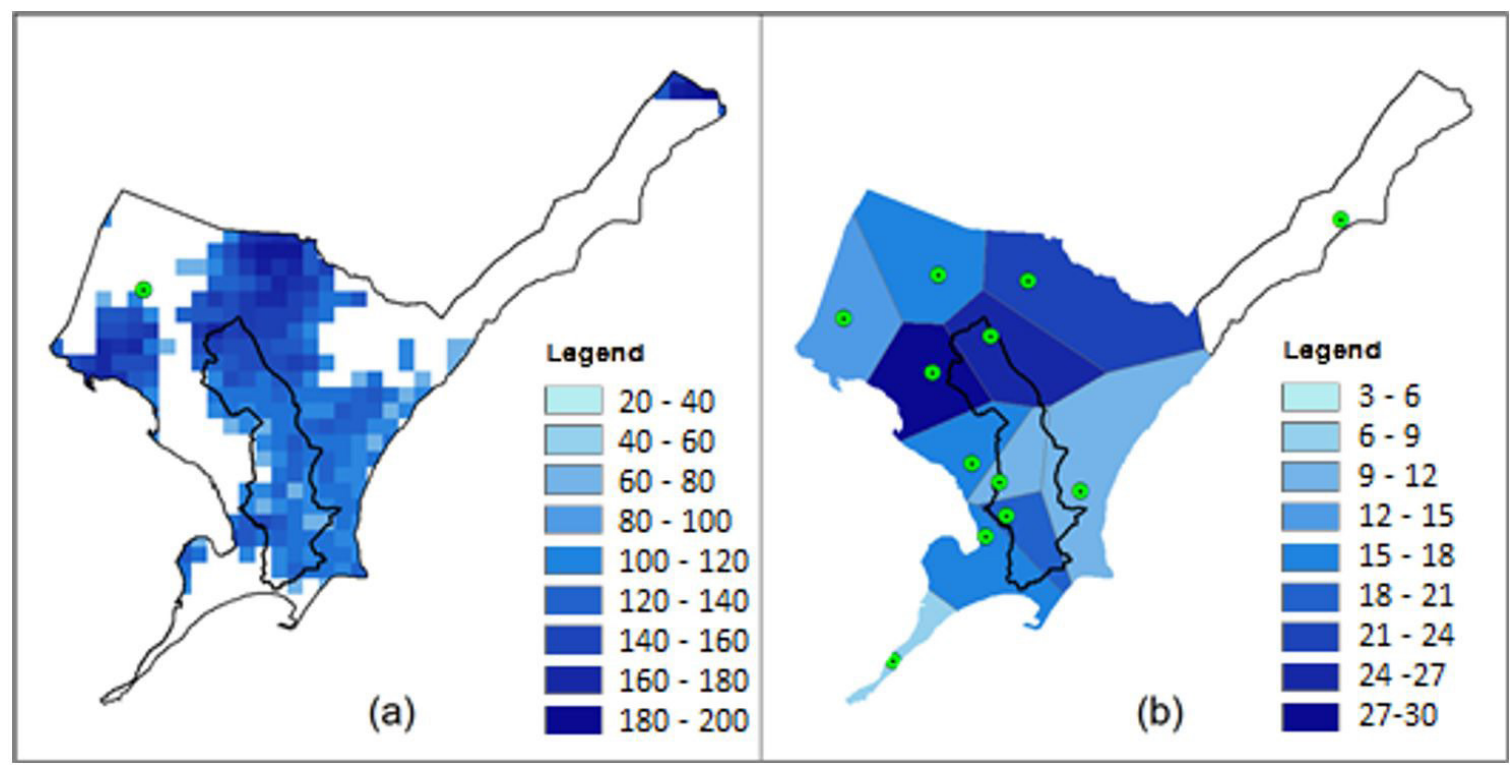

Figure 13. Readings for the same period of time: a) Radar and b) rain gauges (subtitles in mm).

systems is visible (Figure 13), but for a river basin inserted in a region that has a dense rainfall network (density of 3.8 instruments every $10 \mathrm{~km}^{2}$ which is high-density of rainfall network, according to Baronetti et al., 2018) this variation becomes minimal.

\section{CONCLUSIONS}

This study used three scenarios for hydrograph analysis based on different sources of precipitation as an input of a hydrological model coupled with a hydrodynamic model applied to the Reginaldo river basin, which is fully inserted in the urban area of the municipality of Maceió - AL. The simulations were performed using meteorological radar data and rainfall gauge stations, with model parameters defined in previous studies. Regard the spatial characteristics of rainy events, our results suggest that for small urban basins, with large impervious areas and with a dense network of rainfall gauges, the difference between the concentrated and distributed scenarios is minimal, but there is an exception to this statement that occur when the rainfall is concentrated in a small part of the basin.

The combined use of rainfall stations and weather radar has an important role to assess the behaviour of rainy events both spatially and temporally. The application of the rainfall stations, even if they do not have as efficient coverage as the radar, presented results that have the same trends as the results obtained by the radar. On the other hand, the radar, even with an excellent spatial and temporal resolution, showed significantly higher precipitation values compared to the rainfall gauge data, which indicates that the radar either needs a later calibration of the values or an update of the Z-R ratio.

\section{ACKNOWLEDGMENTS}

This research was supported by National Council for Scientific and Technological Development (CNPq - Grant $\left.\mathrm{N}^{\circ}: 425311 / 2016-3\right)$, Coordination for the Improvement of Higher 
Education Personnel (CAPES) and Alagoas State Research Support Foundation (FAPEAL - Grant N: 88887.159732/2017-00 and 60030.000411/2017).

\section{REFERENCES}

Antonio, G.B. (2017). Aplicabilidade de medidas de controle do escoamento superficial: Distribuição espacial na bacia bidrográfica do Rio Reginaldo, Maceió-AL (Dissertação de Mertrado). Universidade Federal de Alagoas, Maceió, AL.

Barco, J., Wong, K. M., \& Stenstrom, M. K. (2008). Automatic calibration of the U.S. EPA SWMM model for a large urban catchment. Journal of Hydraulic Engineering. 134(4), 466-474.

Baronetti, A., Acquaotta, F., \& Fratianni, S. (2018). Rainfall variability from a dense rain gauge network in north-western Italy. Climate Research. 75, 201-213.

Barszcz, M. P. (2018). Radar data analyses for a single rainfall event and their application for flow simulation in an urban catchment using the SWMM Model. Water, 10, 1007.

Bruni, G., Reinoso, R., van de Giesen, N. C., Clemens, F. H. L. R., \& ten Veldhuis, J. A. E. (2015). On the sensitivity of urban hydrodynamic modelling to rainfall spatial and temporal resolution. Hydrology and Earth System Sciences, 19(2), 691-709. http://dx.doi. org/10.5194/hess-19-691-2015.

Cabral, S. L., Sakuragi, J., Angelis, C. F., Silveira, C. S. (2017). Incertezas e erros na estimativa de vazões usando modelagem hidrológica e precipitação por RADAR. Revista Ambiente e Água. 12(1), 57-70.

Calvetti, L., Beneti, C., \& Pereira Filho, A. J. (2003, April). Integração do radar meteorológico doppler do SIMEPAR e uma rede de pluviômetros para a estimativa da precipitação. In Congress proceedings XI Simpósio Brasileiro de Sensoriamento Remoto (pp. 11371144). Belo Horizonte, MG: INPE.

Campos, E. F. (2009). Avaliação da distribuição da chuva nas vazões máximas urbanas usando dados de radar e de pluviógrafo (Dissertação de mestrado). Universidade Estado de Campinas, Campinas, SP.

Denardin, J. L., \& Freitas, P. L. (1982). Características Fundamentais da Chuva no Brasil. Pesquisa Agropecuária Brasileira, 17(10), 1409-1416.

Environmental Systems Research Institute - ESRI. (2018). ArcGIS Desktop: Release 10.5. Redlands, CA: Environmental Systems Research Institute.

Hass Miguel, B. (2018). Uso de dados de radar meteorológico em modelo bidrológico SCS-CN para estimativa de escoamento superficial (Dissertação de mestrado). Instituto Nacional de Pesquisas Espaciais, São José dos Campos, SP.
Holz, J. (2010). Levantamento e mapeamento do indice de risco de alagamento da bacia do Riacho Reginaldo (Dissertação de mestrado). Universidade Federal de Alagoas, Maceió, AL.

Leach, J. M., Kornelsen, K. C., \& Coulibaly, P. (2018). Assimilation of near-real time data products into models of an urban basin. Journal of Hydrology, 563, 51-64. http://dx.doi.org/10.1016/j. jhydrol.2018.05.064.

Lee, J., Kim, S., \& Jun, H. (2018). A study of the influence of the spatial distribution of rain gauge networks on areal average rainfall calculation. Water (Basel), 10(11), 1635. http://dx.doi. org/10.3390/w10111635.

United States Environmental Protection Agency - USEPA (2017). User Manual SWMM. V. 5.1.012. Cincinnati, OH: USEPA.

Marshall, J. S., \& Palmer, W. (1948). The distribution of raindrops with size. Journal of Meteorology, 5(4), 165-166. http://dx.doi. org/10.1175/1520-0469(1948)005<0165:TDORWS>2.0.CO;2.

Adilson Moreira, I., Moro Mine, M. R., \& Pereira Filho, A. J. (2007). Modelagem hidrológica chuva-vazão com dados de radar e pluviômetros. Ingeniería del Agua, 14(2), 83-96. http://dx.doi. org/10.4995/ia.2007.2904.

Tenório, R. S., Moraes, M. C. S., \& Sauvageot, H. (2012). Raindrop size distribution and radar parameters in coastal tropical rain systems of northeastern Brazil. Journal of Applied Meteorology and Climatology, 51(11), 1960-1970. http://dx.doi.org/10.1175/ JAMC-D-11-0121.1.

Pedrosa, H. F. S. (2008). Avaliação do impacto da aplicação das diretrizes do plano diretor de Maceió sobre o escoamento superficial. Estudo de caso: Bacia do Riacho Reginaldo (Dissertação de mestrado). Universidade Federal de Alagoas, Maceió, AL.

Pereira Filho, A. J., Crawford, K. C., \& Hartzell, C. (1998). Improving WSR-88D hourly rainfall estimates. Weather and Forecasting, 13(4), 1016-1028. http://dx.doi.org/10.1175/15200434(1998)013<1016:IWHRE>2.0.CO;2.

Pfafstetter, O. (1957). Chuvas Intensas no Brasil (2a ed., 419 p.). Rio de Janeiro, RJ: DNOS.

Rico-Ramirez, M. A., Liguori, S., \& Schellart, A. N. A. (2015). Quantifying radar-rainfall uncertainties in urban drainage flow modelling. Journal of Hydrology, 528, 17-28. http://dx.doi. org/10.1016/j.jhydrol.2015.05.057.

Rocha Filho, K. L. (2010). Modelagem bidrológica da bacia do rio Pirajucara com TOPMODEL, telemetria e radar meteorológico (Dissertação de mestrado). Universidade de São Paulo, São Paulo.

Rossman, L. A. (2015). Storm Water Management Model User's Manual Version 5.1. Cincinnati, OH: National Risk Management Research Laboratory, United States Environmental Protection Agency. 
Santos, P. R. (2018). Análise de métodos para obtenção de chuvas intensas para a cidade de Maceió (Dissertação de mestrado). Universidade Federal de Alagoas, Maceió, AL.

Shinma, T. A., \& Reis, L. F. (2014). Incorporating Multi-event and Multi-site Data in the Calibration of SWMM. Procedia Engineering, 70, 75-84. http://dx.doi.org/10.1016/j.proeng.2014.02.010.

Shinma, T. A. (2015). Avaliação de incertezas na calibração automática do modelo SWMM (Tese de doutorado). Universidade de São Paulo, São Paulo, SP.

Schuurmans, J. M., \& Bierkens, M. F. P. (2007). Effect of spatial distribution of daily rainfall on interior catchment response of a distributed hydrological model. Hydrology and Earth System Sciences, 11(2), 677-693. http://dx.doi.org/10.5194/hess-11-677-2007.

Silva Júnior, R. I. (2009). Evolução da urbanização e seu efeito no escoamento superficial na bacia do Riacho Reginaldo, Maceió - AL (Dissertação de mestrado). Universidade Federal de Alagoas, Maceió, AL.

Smith, D., Li, J., Banting, D. A. (2005). PCSWMM/GIS-based water balance model for the Reesor Creek watershed. Atmospheric Research, 77(1-4), 388-406.

Souza, T. C. T. (2017). Avaliação de vazõos máximas estimadas a partir dos modelos HEC-HMs e SWMM - estudo de caso para o núcleo urbano e região periurbana de Muniz Freire (Dissertação de mestrado). Federal University of Espírito Santo, Vitória, ES.

Tayob, L. J. D. (2014). Determinação da relação entre a intensidade da chuva e refletividade radar no litoral do estado de Alagoas usando disdrômetro a laser (Dissertação de mestrado). Universidade Federal de Alagoas, Maceió, AL.
Tsuji, T. M., Costa, M. E. L., \& Koide, S. (2019). Diffuse pollution monitoring and modelling of small urban watershed in Brazil Cerrado. Water Science and Technology, 79(10), 1912-1921. PMid:31294708. http://dx.doi.org/10.2166/wst.2019.190.

\section{Authors contributions}

Victor Costa Pontes: Performed the research, survey and data analysis, analysis and discussion of the results and writing of the article.

Carlos Ruberto Fragoso Jr.: Contributed to the conception of the work, data analysis, discussion of results and revision of the article.

Marllus Gustavo Ferreira Passos das Neves: Contributed to the conception of the work, data analysis, discussion of results and revision of the article.

Vladimir Caramori Borges de Souza: Research supervisor and work advisor, contributed to the work design, data analysis, discussion of results, writing and final revision of the article.

Editor in-Chief: Adilson Pinheiro.

Associated Editor: André Schardong. 